\title{
"The role of managers' education inpromoting social responsibility level in Saipa Diesel Company in Iran"
}

\author{
${ }^{1}$ Somayyeh javidi, ${ }^{2}$ Saeed khajei \\ ${ }^{1,}$ Student of Education management, Central tehran branch, Islamic Azad University, Tehran, Iran \\ ${ }^{2}$ Department of Education management, Central tehran branch, Islamic Azad University, Tehran, Iran
}

\begin{abstract}
Generally, the organizations establishing primary approach was aimed to earn profit for their shareholders. This approach gradually is faced with many challenges with the passage of time and the occurrence of environmental changes. Moreover, the needs and desires of humans today has changed because of the changes which has occurred in the environment around the organizations, and gradually, considering the different concepts such as environment and conserving natural resources for future generations, the development of social welfare, attention to social responsibility and such issues has become a concern to community and organizations. Today, organizations cannot no longer be indifferent towards social responsibilities alike the past, and perhaps dare to say that in the not too distant future, the basis for selecting an organization to receive goods or services from a customer perspective, will be the level of respect to organizational commitment to observe social responsibilities. Also this issue is one of the important issues in recent years that has been investigated by the researchers. In this context, the main aim of this study is to investigate the role of managers' education in promoting social responsibility level in Saipa Diesel Company, which is done in descriptive-survey method. Statistical population of Saipa Diesel includes managers and employees numbering 998 people, of whom 280 people were selected as sample according to the Kokaran formula. Sampling method of the study is the simple random one. The scholar's questionnaire was used to collect the data containing 27 questions. Its validity has been confirmed by several experts and its reliability has been confirmed using Cronbach's alpha for the 25 persons pretested 0.91. The collected data of the statistical tests (t-dependent) were analyzed. The results showed that managers' education is effective on promoting the level of social responsibility in Saipa Diesel Company. Also the other assumptions showed that managers' education has been influential to formulate the system of social responsibility, awareness of managers about promoting social responsibility and growing social responsibility in organization level, and only the effect of education for justifying the managers towards improving the social responsibility was not confirmed.
\end{abstract}

Keywords: Education, social responsibility, social responsibility system and the promotion of social responsibility

\section{Introduction}

Present age is called the Management Age, because every decision a manager makes, sooner or later, can change the fate of the society institutions, in a set of trends. One of the social problems in recent years, to which many scholars and practitioners of various communities have been attracted, is the lack of adherence to the duties and responsibilities by organizations and their managers. In fact, it was once thought that organizations are merely responsible for the shareholders and employees, or the best consumer products with lower price and higher quality should conveyed to the customer, unaware of the further consequences. Actually, research on organizational activities outcomes have been created new approaches to the organization and management, from which, social obligation and responsibility are resulted. In other words, today's organizations social responsibility, has a wider sense from past activities, and in general, refers to the activities which business owners and economic institutions voluntarily, perform as effective and useful members of society. Also the social responsibility discussion is proposed in organizations as a challenging and interesting subject of discussion in managerial research.

\section{Problem Description}

In today's competitive environment, organizations responsibility is essential factor for survival of any organization, and social responsibility is an important issue in modern management, since the organizations and companies lack of attention to the social responsibility prevents them from effectively serving the community and organizational development and validation. Indeed, thinkers of management field since the 1950s, have focused their attention more to the social responsibilities of organizations. About definition of social responsibility, different views has been raised. In fact, one of the fundamental problems of social sciences is that scientists cannot offer single definition of terms and applied concepts social responsibility is not apart from the subject, because about the definition of the unit between management scientists, there is no consensus. But to understand more of this concept, the different definitions are presented in the following. Social responsibility is 
the duty of the private institutions which include tasks such as not to pollute environment, not to discriminate in employing, not doing unethical practices and to inform consumers of product quality and positive involvement in the lives of individuals.In this regard, Griffin and Barney identify the social responsibility as a set of duties and obligations that organization must do in order to maintain, promote and help a society in which they work and avoid the production of harmful products and so that are harmful for public health, And must try to allocate financial resources to social welfare that is accepted by the majority of society. Since Iran was accepted as an observer member in World Trade Organization and in the future it will join to it, it is necessary to Iranian organizations to consider standards and principles in this area, one of which is paying attention to social responsibility. Actually, Corporate Social Responsibility is an issue that must be considered by the organization's managers to think ahead. In other words it can be stated that social responsibilities and business ethics are more emphasized issues in organizations today.

\section{Assumptions}

The main objective of this study was to evaluate the role of education in promoting social responsibility level in Saipa Diesel Company, which raises following hypothesizes:

- Training managers has influenced in the formulation of social responsibility system in Saipa Diesel Company;

- Training has influenced the knowledge and belief of senior managers towards promoting social responsibility in Saipa Diesel Company;

- Training has influenced in justifying managers and employees towards improving social responsibility in Saipa Diesel Company;

- Training has influenced the on growing organizational level of social responsibility in Saipa Diesel Company;

\section{Methods and Research Tools}

Scientific research is an effort and seriousness for argument, inference and discovering partial truth about a topic or issue. So, research method in every branch of science includes all options and rules applied for the conduct of research. In this regard, the research method used in this research is descriptive in nature. Because this study is to describe the real situation of variables. Among the different types of descriptive methods is survey.

According to this study aim, it is a practical one. According to method of data collection, it is field research. Because the researcher directly has referred to Saipa Diesel company to collect data and has collected data through questionnaires.

Questionnaire of this study is consisted of 27 questions that questions 1 to 5 corresponding to the formulating of social responsibility system, questions 6 to 10 corresponding to the managers awareness towards promoting of social responsibility, questions 11 to 16 corresponding to justify managers to improve social responsibility and questions 16 to 27 corresponding to promote social responsibility level in the organization. For coding questions, a five-item Likert scale was used to assess how each scale is scored in Table 1.

Table 1: Five-item Likert scales and how to score each scale

\begin{tabular}{|c|c|c|c|c|}
\hline Very much & Much & moderately & low & Very low \\
\hline 5 & 4 & 3 & 2 & 1 \\
\hline
\end{tabular}

To assess the validity of the questionnaire, expert's opinions was used and Cronbach's alpha was used to assess its reliability. The alpha values for each of the dimensions and the whole questionnaire is shown in Table 2.

Table 2: Cronbach's alpha value related to each variable

\begin{tabular}{|c|c|}
\hline Cronbach's alpha & variables \\
\hline 0.84 & the formulating of social responsibility system \\
\hline 0.91 & managers awareness towards promoting of social responsibility \\
\hline 0.88 & to justify managers to improve social responsibility \\
\hline 0.92 & to promote social responsibility level in the organization \\
\hline 0.91 & total \\
\hline
\end{tabular}

\section{Analysis of research hypotheses}

Check the condition of normal distribution of data: to show that the variables have normally distributed, Kolmogorov - Smirnov test has been used. In this test, the null hypothesis is based on being normal distribution. If the significance level is less than 0.05 , it indicates that studied variables don't have not normal distribution. Results of Kolmogorov - Smirnov test are presented in Table 3. 
Table 3: Results of Kolmogorov - Smirnov test

\begin{tabular}{|c|c|c|}
\hline Significance level & test statistic value & \\
\hline 0.716 & 0.65 & the formulating of social responsibility system \\
\hline 0.367 & 0.92 & managers awareness towards promoting of social responsibility \\
\hline 0.082 & 1.30 & to justify managers to improve social responsibility \\
\hline 0.671 & 0.84 & to promote social responsibility level in the organization \\
\hline 0.134 & 1.12 & Whole questionnaire \\
\hline
\end{tabular}

Given the significant levels are above 0.05 , null hypothesis based on being normal distribution is accepted; so normality conditions studied variables to estimate the unknown parameters are significant. Now, We continue to test research hypotheses based on parametric methods.

Analysis of research hypotheses: Since the data in the two conditions before the training courses and after training have been collected, thus pair-wise comparison test (t-dependent) is used. A comparison in table 4 between total scores of statistics sample and score mean of above index in two different periods before training and after training for all variables is made.

Table 4: Comparison of the mean of scores for the variables before and after training

\begin{tabular}{|c|c|c|c|c|c|}
\hline $\begin{array}{c}\text { to promote } \\
\text { social } \\
\text { responsibility }\end{array}$ & $\begin{array}{c}\text { to grow social } \\
\text { responsibility }\end{array}$ & $\begin{array}{c}\text { to justify } \\
\text { managers }\end{array}$ & $\begin{array}{c}\text { managers } \\
\text { awareness }\end{array}$ & $\begin{array}{c}\text { the formulating of } \\
\text { social responsibility } \\
\text { system }\end{array}$ & \\
\hline 27 & 12 & 5 & 5 & 5 & $\begin{array}{c}\text { Numbers of } \\
\text { indices }\end{array}$ \\
\hline 88.2 & 40.67 & 16.27 & 14.82 & 16.44 & before training \\
\hline 105.84 & 48.11 & 18.04 & 20.31 & 19.38 & after training \\
\hline
\end{tabular}

In the following, in Table 5, Pair-wise comparison test results ( $t$-dependent) for the research hypotheses are presented.

Table 5: test result for comparison the two periods based on variables

\begin{tabular}{|c|c|c|c|c|}
\hline Test result & $\begin{array}{c}\text { Significance } \\
\text { level }\end{array}$ & $\begin{array}{l}\text { Degree of } \\
\text { freedom }\end{array}$ & $\begin{array}{l}\text { Statistic t } \\
\text { value }\end{array}$ & \\
\hline $\begin{array}{c}\text { confirmation } \\
\mathrm{H}_{1}\end{array}$ & 0.001 & 279 & -5.628 & $\begin{array}{l}\text { the formulating of social } \\
\text { responsibility system }\end{array}$ \\
\hline $\begin{array}{c}\text { confirmation } \\
\mathrm{H}_{1}\end{array}$ & 0.000 & 279 & -8.233 & managers awareness \\
\hline $\begin{array}{c}\text { confirmation } \\
\mathrm{H}_{0}\end{array}$ & 0.064 & 279 & -1.47 & To justify managers \\
\hline $\begin{array}{c}\text { confirmation } \\
\mathrm{H}_{1}\end{array}$ & 0.000 & 279 & -8.699 & to grow social responsibility \\
\hline $\begin{array}{c}\text { confirmation } \\
\mathrm{H}_{1}\end{array}$ & 0.000 & 279 & -6.12 & to promote social responsibility \\
\hline
\end{tabular}

According to Table 5, the values of the significance level except the third hypothesis (to justify managers) are less than $\alpha=0.05$ test error level. In fact it can be stated that in the 0.95 probability level, hypothesis $\mathrm{H} 0$ is rejected and $\mathrm{H} 1$ is confirmed and it can be stated that there is difference between different indices mean before and after training managers. And since indices mean after the training is increased than before, so we can conclude training managers is influenced to promote social responsibility level indicators and its indices except justifying managers in Saipa Diesel company.

\section{Conclusions}

Based on deduction analysis of data related to first hypothesis, training managers has influence on the formulating of social responsibility system in Saipa Diesel Company. In fact, based on results of this study, managers and employees believed that after training courses in Company for managers, managers had been attracted to formulating code of ethics and extending and formulating capability principles of employees for applying social responsibility. Also, based on analysis, second hypothesis based on awareness of senior managers towards promoting social responsibility was confirmed. Actually, results of the study show that training courses make managers aware of extending and maximizing social purposes and accountability criteria and try to promote social responsibility level. Third hypothesis based on effect of training on justifying 
managers towards improving social responsibility level in the company was not confirmed. In fact, based on results of the study, persons responsible for believed that training didn't make managers justify towards promoting social responsibility level. But about growing social responsibility in organization level in the company, it should be stated that training is in influenced on it. Actually, based on results of the study, employees believed that because of managers training, non ethical works have been reduced in the company and it avoids sabotage between employees. The organization become to social institution and altruism culture in interactions and trust of organization have been extended (among employees, stakeholders, customers, competitors and etc). Also customers are justified for using better organizational services and accountability of managers to owners and society is increasing.

\section{Reference}

[1]. Greening, D. W. and D. B. Turban (2000): Corporate Social Performance as a Competitive Advantage in Attracting a Quality Work Force, Business \& Society, Vol. 39, No. 3, pp: 254-280.

[2]. koontz (1998) Management and Society: Social Responsibility and Ethics. New York: Mcgraw, chap.2.pp: 29 - 39

[3]. Owen, Daniel P.(2007). Beyond Corporate Social Responsibility: The Scope for Corporate Investment in Community Driven Development. World Bank Report No. 37379-GLB.

[4]. Salehi, M. and Azary, Z. (2009): Stakeholders' Perceptions of Corporate Social Responsibility: Empirical Evidences from Iran, International Business Research, Vol. 2, No. 1.

[5]. Sims, R. R. (2003): Ethics and Corporate Social Responsibility: Why Giants Fall, Praeger Publishers, USA.

[6]. Sharada, W. (2007) The Effect of Education of Farmer Productivity in Rural Ethiopia: Http:// www.csae.ox.ac.uk./workingpapers.

[7]. Smith, J. J. (2006). HR should urge adoption of, corporate social responsibility, policy. SHRM Global HR News.

[8]. Takala, T. and Pallab, P. (2000): Individual, Collective and Social Responsibility of the Firm, Business Ethics: A European Review, Vol. 9, No.2, pp: 109-118.

[9]. Turker, D. (2009): How Corporate Social Responsibility Influences Organizational Commitment, Journal of Business Ethics, Vol. 89, pp: $189-204$.

[10]. Yongqiang, G. (2009): Corporate Social Responsibility and Consumers' Response: the Missing Linkage, Baltic Journal of Management, Vol. 4, No. 3, pp: 269-287.

[11]. Zairi, M. and Peters, J. (2002): The Impact of Social Responsibility on Business Performance, Managerial Auditing Journal, Vol. 17, No. 4, pp: 174-178. 